\title{
Integrasi Regional Eropa Pasca Krisis Pengungsi 2015: Peran Area Schengen dalam Rekonstruksi Identitas Eropa melalui 'Spatial "Othering"
}

\author{
Tara Kukuh Wardhani \\ Universitas Airlangga
}

\begin{abstract}
ABSTRAK
Tulisan ini berangkat dari perdebatan mengenai relevansi motif-motif fungsional maupun neo-fungsional, seperti ekonomi, politik, dan mobilitas bagi Uni Eropa untuk tetap mempertahankan pengadaan area Schengen setelah berbagai ancancaman ketikdamanan yang muncul pasca derasnya arus masuk pengungsi pada tahun 2015. Permasalahan tersebut menjadi penting karena pengadaan area Schengen telah menjadi salah satu pendorong integrasi regional Eropa sejak ditetapkan dalam Perjanjian Amsterdam tahun 1999. Maka dari itu, perlu analisis lebih lanjut untuk menjelaskan motif lain yang mendasari keputusan Uni Eropa untuk tetap mempertahankan pengadaan area Schengen. Hasil analisis penulis menunjukkan tiga temuan terkait keputusan tersebut. Pertama, mpeneliti menganalisis adanya transisi bentuk 'ordering' area Schengen dalam proses integrasi Eropa, dari yang awalnya bersifat fungsional menjadi sarat motif identitas. Kedua, peneliti menemukan praktik 'bordering' melalui pengadaan area Schengensebagai bentuk upaya untuk mendekonstruksi identitas geografis rigid Eropa menjadiidentitas geopolitik spasial sehingga mempertegas eksklusi terhadap negara-negara non-Eropa. Ketiga, peneliti menganalisis adanya kemungkinan peningkatan derajat inklusivitas Uni Eropa sebagai respon strategis terhadap krisis Schengen.
\end{abstract}

Kata Kunci: Area Schengen, Uni Eropa, Integrasi Regional, Identitas, 'Ordering', 'Bordering', 'Spatial “Othering”, Krisis Pengungsi

This paper departs from the debate on the relevance of functional and neofunctional motives, such as economics, politics, and mobility, to the EU to maintain the procurement of the Schengen area in the aftermath of insecurity crisis caused by the large influx of refugees in 2015. This issue is important because the Schengen area has been one of the drivers of European regional integration. Thus, a more thorough analysis is needed in order to clarify other motives underlying the EU's decision to maintain the procurement of the Schengen Area. Consequently, the author's analysis yields three major findings to review motives regarding the issue. First, the author analyses the transition of Schengen's 'ordering'forms in the European integration process, from functional to identity-driven motives. Second, the author analyses the 'bordering' practices undertaken by the EU through the Schengen area as an attempt to deconstruct the European rigid geographical identity into a spatial geopolitical identity thus reinforcing exclusion of countries non-European. Third, the author analyses the possibility of increasing degrees of EU inclusiveness as a strategic response to the Schengen crisis.

Keywords: Schengen Area, European Union, Regional Integration, Identity, 'Ordering', 'Bordering', 'Spatial “Othering”, Refugee Crisis 


\section{Pendahuluan}

Setelah Perang Dunia II, peningkatan integrasi regional Eropa terus dilakukan dalam beberapa tahap melalui kerangka institusi Uni Eropa untuk mencegah terjadinya peperangan yang lebih besar di kawasan (Spolaore, 2013). Sampai pada Perjanjian Amsterdam tahun 1999, Uni Eropa semakin memperdalam integrasi regionalnya dengan mengadopsi area Schengen ke dalam kerangka institusi legalnya, yaitu untuk mengatur pergerakan lintas batas yang mencakup pergerakan bebas manusia, jasa dan barang, kebijakan imigrasi dan suaka, perlintasan perbatasan eksternal bersama, hingga kerja sama bea cukai dan peradilan sipil, yang kemudian dikenal sebagai Schengen Acquis (EurLex, 2000). Meskipun awalnya area Schengen yang digagas oleh Perancis, Jerman, Belgia, Belanda, dan Luksemburg pada taun 1985 ini dibentuk terpisah dari kerangka Uni Eropa, namun pembahasan mengenai area Schengen secara lebih lanjut menjadi penting karena menurut Komisi Eropa (2017), area Schengen merupakan salah satu pencapaian paling besar dan konkret bagi Uni Eropa.

Pernyataan tersebut kemudian melandasi keinginan peneliti untuk melakukan penelitian lebih lanjut mengenai fitur-fitur distingtif yang dimiliki oleh area Schengen dalam mendukung integrasi Eropa. Fitur pertama, dalam aspek mobilitas, area Schengen menjadikan Eropa satu-satunya tempat yang menjamin pergerakan bebas masyarakat hingga mencapai lebih dari 3,5 juta orang setiap harinya (Komisi Eropa, 2015). Fitur kedua, dalam aspek perluasan, area Schengen dapat memperluas keanggotaannya secara mandiri yang berbeda dari perluasan institusi Uni Eropa hingga saat ini area Schengen telah mencakup 22 dari 28 negara anggota Uni Eropa serta empat negara non-Uni Eropa (Parlemen Eropa, 2018). Fitur ketiga, dalam aspek ekonomi, area Schengen berperan penting dalam meningkatkan pertumbuhan ekonomi regional Eropa karena hingga tahun 2016, padalevelnegara. Pasalnya,jika dua negara anggota Schengen mengadakan kerja sama dagang bilateral, maka hasil perdagangan bersih dapat mencapai 0,09 persen per tahun (Parlemen Eropa, 2016). 


\section{Gambar 1. Peta Area Schengen: Uni Eropa non-Schengen dan Schengen non-Uni Eropa}

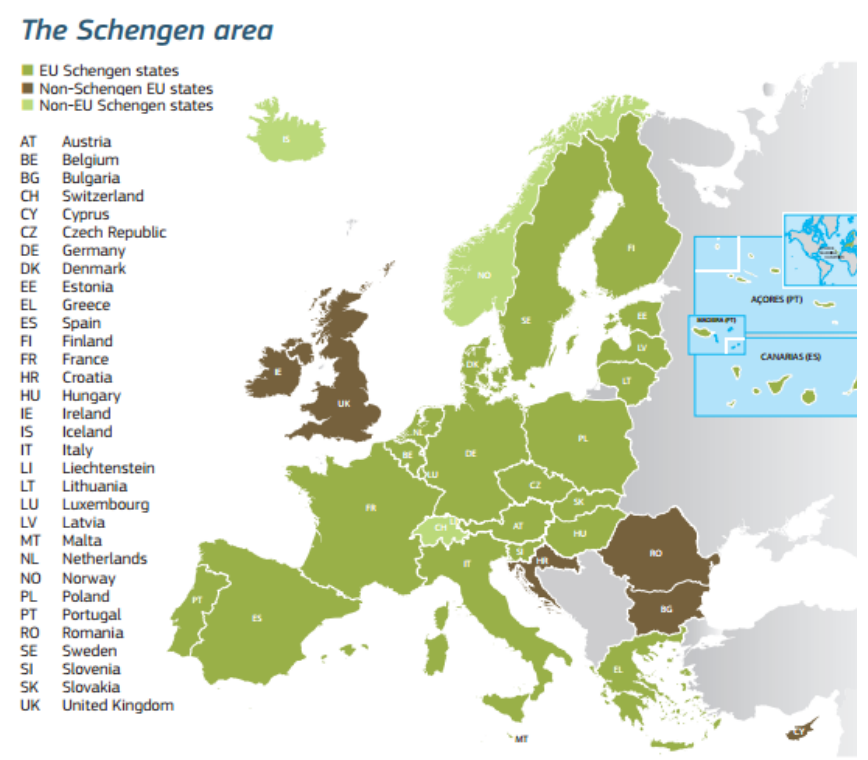

Sumber: Komisi Eropa, 2011

Akan tetapi, seiring dengan munculnya berbagai macam krisis yang menimpa Eropa dalam satu dekade terakhir, area Schengen justru menimbulkan permasalahan-permasalahan baru bagi Eropa yang belum pernah terjadi sebelumnya. Pertama, diterapkannya penghapusan kontrol perbatasan internal dalam area Schengen, dapat memunculkan kemungkinan bahaya dari arus migrasi, terutama saat terjadinya krisis pengungsi pada tahun 2015, yang berpotensi mempermudah persebaran teroris dalam area Schengen (Jenkins, 2016). Kedua, menurut George Soros, seorang politisi Hungaria yang juga merupakan pencetus Open Society Foundation, Uni Eropa akan membutuhkankuranglebih 30 miliareuropertahun untuk membangun lembaga perbatasan dan suaka, mengatur prosedur penerimaan pengungsi, dan membuka kemungkinan para pengungsi untuk dapat berbaur dengan masyarakat Eropa (Parlemen Eropa, 2016). Bahkan Wolfgang Schäuble selaku Menteri Keuangan Jerman, menyatakan bahwa area Schengen akan mengalami kegagalan karena kerja sama yang lebih efektif membutuhkan biaya yang sangat besar. Oleh karena itu, dapat dilihat bahwa area Schengen yang sebelumnya menguntungkan sektor ekonomi dan mobilitas negaranegara Eropa justru relatif menimbulkan kerugian material maupun sosial ketika dihadapkan pada krisis pengungsi. 
Dalam merespon fenomena "free movement of terrorists" ini, berbagai negara anggota Schengen akhirnya mulai menerapkan kembali kontrol perbatasan internalnya. Skeptisisme terhadap area Schengen juga muncul pada jajaran pimpinan negara-negara Eropa. Bahkan, Donald Tusk, Presiden Dewan Eropa, telah memberi pernyataan kepada Parlemen Eropa pada tahun 2016, bahwa apabila Uni Eropa tidak dapat menyelesaikan permasalahan kemanusiaan yang terjadi, area Schengen terancam harus dibubarkan (Aamann, 2016). Oleh karenanya, menjadi menarik untuk dibahas karena sampai saat ini area Schengen masih diperjuangkan untuk terus diberlakukan oleh Uni Eropa. Jean-Claude Juncker, Presiden Komisi Eropa, dengan tegas menyatakan "I'm not going to give up on Schengen, I reject the idea that this is somehow the beginning of an end" (Dallison, 2016). Meskipun relevansi atas pernyataan Komisi Eropa bahwa area Schengen merupakan pencapaian terbesar proses integrasi Eropa seperti yang telah dijelaskan peneliti di awal patut untuk dipertanyakan. Hal ini dikarenakan, berbagai keuntungan dari fitur-fitur esensial yang dibawa oleh area Schengen, seperti aspekmobilitas, inklusivitas regional, dan ekonomi, berangsur-angsur bergeser menjadi beban kerja sama regional, terutama pasca terjadinya krisis pengungsi.

\section{Tabel 1. Negara-negara Anggota Schengen yang Member- lakukan Kembali Kontrol Perbatasan Internal pada Tahun 2016}

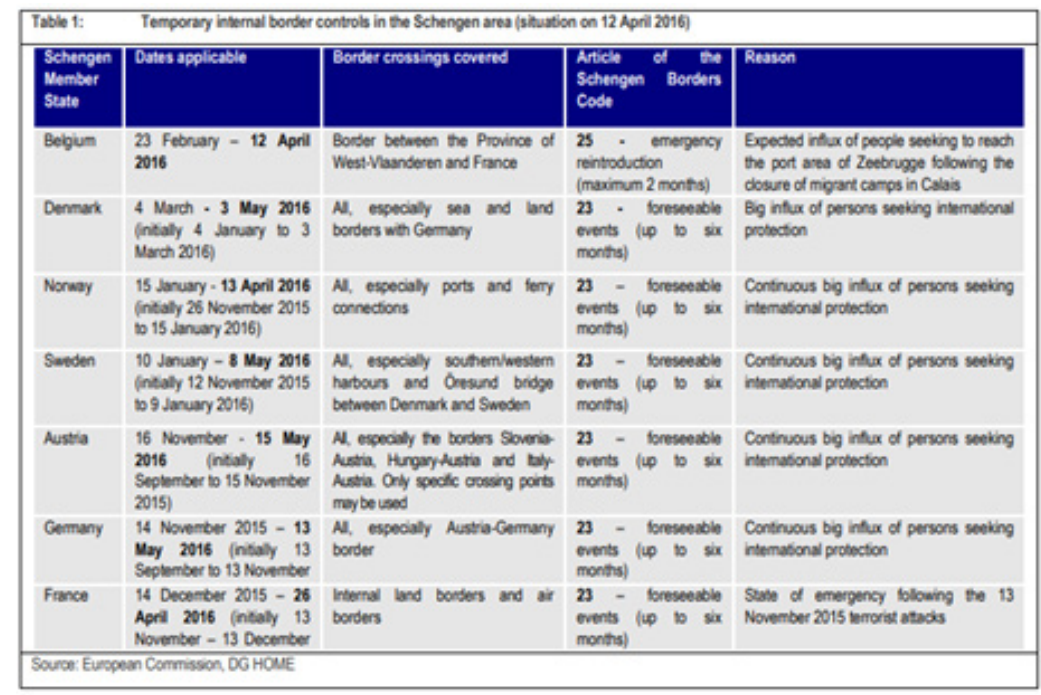

(Sumber: Parlemen Eropa, 2016) 


\section{Instrumen Analisis Rekonstruksi Identitas Eropa melalui Area Schengen}

Dalam kajian regionalisme kontemporer, terdapat tiga motif yang dapat digunakan untuk menganalisis integrasi regional yang bersifat multidimensional. Pertama, motif ekonomi berdasarkan pendekatan fungsionalisme klasik. Kedua, motif politik berdasarkan pendekatan neo-fungsionalisme. Ketiga, motif identitas berdasarkan pendekatan konstruktivisme sosial (Farrell et al., 2005). Peneliti kemudian berfokus pada analisis motif identitas dalam menjelaskan upaya integrasi Eropa melalui area Schengen karena motif ekonomi dan politik tidak lagi terlalu signifikan. Akan tetapi, pendekatan konstruktivisme sosial memiliki keterbatasan dalam menganalisis identitas yang dibentuk melalui area Schengen, yang mana tidak berada pada ranah normatif ataupun linguistik (Checkel, 2006). Maka peneliti menggunakan pendekatan posfungsionalisme sebagai instrumen analisis yang mengidentifikasi motif identitas dalam 'ordering' area Schengen. Namun, pendekatan postfungsionalisme sendiri tidak menjelaskan secara lebih lanjut mengenai bentuk dari identitas yang dikonstruksikan sehingga peneliti menggunakan teori Geopolitik Kritis untuk mengkaji bentuk identitas dan teritorialitas yang dikonstruksikan melalui area Schengen. Lebih lanjut, praktik inklusi dan eksklusi dalam upaya 'bordering' akan dijelaskan menggunakan konsep "spatial "othering".

'Spatial "othering" merupakan istilah geopolitik 'othering' yang menjelaskan dikonstruksikannya eksklusivitas teritorial untuk membentuk identitas (Prozorov, 2011). Strategi 'otherness' tidak berarti mengusir secara fisik, namun memarjinalkan secara politis. Identitas dipersepsikan terbentuk secara interaktif yaitu tidak hanya dengan secara positif mendefinisikan diri sendiri atau 'what it is'. Namun sebaliknya, mendefinisikan 'what it is not'. Maka dapat dilihat bahwa pembahasan mengenai identitas tidak terlepas dari pembahasan mengenai perbedaan, yang salah satunya dapat dicapai melalui pembentukan batasan-batasan atau demarkasi antara 'inside' dan 'outside', 'self' dan 'other', ataupun 'domestic' dan 'foreign' (Derrida, 1968).

Penting untuk membentuk tembok atau batasan yang mengonstruksikan ruang 'inside', yaitu bagi masyarakat yang dianggap beradab, dan 'outside', yaitu bagi masyarakat yang dianggap sebaliknya. 'Bordering' kemudian didefinisikan sebagai konsekuensi dari praktik-praktik 'othering' untuk mengamankan 
identitas (Houtum dan Naerssen, 2001). Dengan kata lain, entitas politik yang dianggap tidak berada di dalam satu kawasan yang sama akan secara langsung maupun tidak langsung dieksklusikan. Pada saat yang bersamaan, derajat inklusivitas antar negara yang dianggap berada di dalam satu kawasan yang sama akan meningkat. Akan tetapi, demarkasi untuk membedakan 'self' dan 'other' bukan hal yang mudah (Campbell, 1990). Hal ini disebabkan oleh adanya area abu-abu dalam masyarakat karena tidak menutup kemungkinan akan ada masyarakat yang dianggap 'other' tinggal di ruang 'inside'.

Oleh karenanya, peneliti berargumen bahwa pasca berbagai krisis ketidakamanan, area Schengen tetap dipertahankan oleh Uni Eropa dalam skema integrasi regional karena Schengen tidak hanya memiliki peran-peran fungsional, yang ditunjukkan dengan adanya tiga indikasi berikut. Pertama, area Schengen mengalami transisi bentuk 'ordering', yaitu dari bersifat fungsional hingga menjadi sarat motif identitas. Kedua, area Schengen berperan untuk mendekonstruksi identitas geografis rigid Eropa menjadi identitas geopolitik spasial, sehingga praktik 'bordering' berimplikasi terhadap dieksklusikannya entitas yang dianggap non-Eropa. Ketiga, berbagai krisis justru mendorong negara-negara anggota Schengen untuk meningkatkan implementasi 'spatial "othering"' dengan meningkatkan derajat inklusivitas kerja sama antar negara sebagai respon strategis.

\section{Analisis Pendekatan Postfungsionalisme dalam Transisi 'Ordering' Area Schengen}

Meskipun awalnya, area Schengen merupakan bentuk 'order' dari pergerakan bebas proyek Internal Market Eropa (Joannin, 2014). Namun, seiring dengan terjadinya berbagai krisis ketidakamanan, utamanya pasca krisis pengungsi pada tahun 2015. Logika berpikir fungsionalisme ataupun neofungsionalisme tidak dapat menjelaskan alasan-alasan di balik dipertahankannya pengadaan area Schengen di bawah kerangka Uni Eropa sebagai salah satu pendukung integrasi regional. Dikarenakan menurut peneliti logika-logika fungsionalisme maupun neofungsionalisme seperti keuntungan ekonomi, politik, dan mobilitas sudah tidak terlalu relevan. Maka, peneliti mencoba untuk menjelaskan dengan logika berpikir posfungsionalisme sebagai identifikasi awal terkait motif dipertahankannya pengadaan area Schengen dalam skema 
integrasi regional Uni Eropa. Oleh karenanya, untuk mempermudah pemahaman transisi 'ordering' area Schengen, peneliti memetakan skema politisasi area Schengen dalam bagan berikut:

\section{Bagan 1. Skema Politisasi Area Schengen dalam Proses Integrasi Regional Eropa}

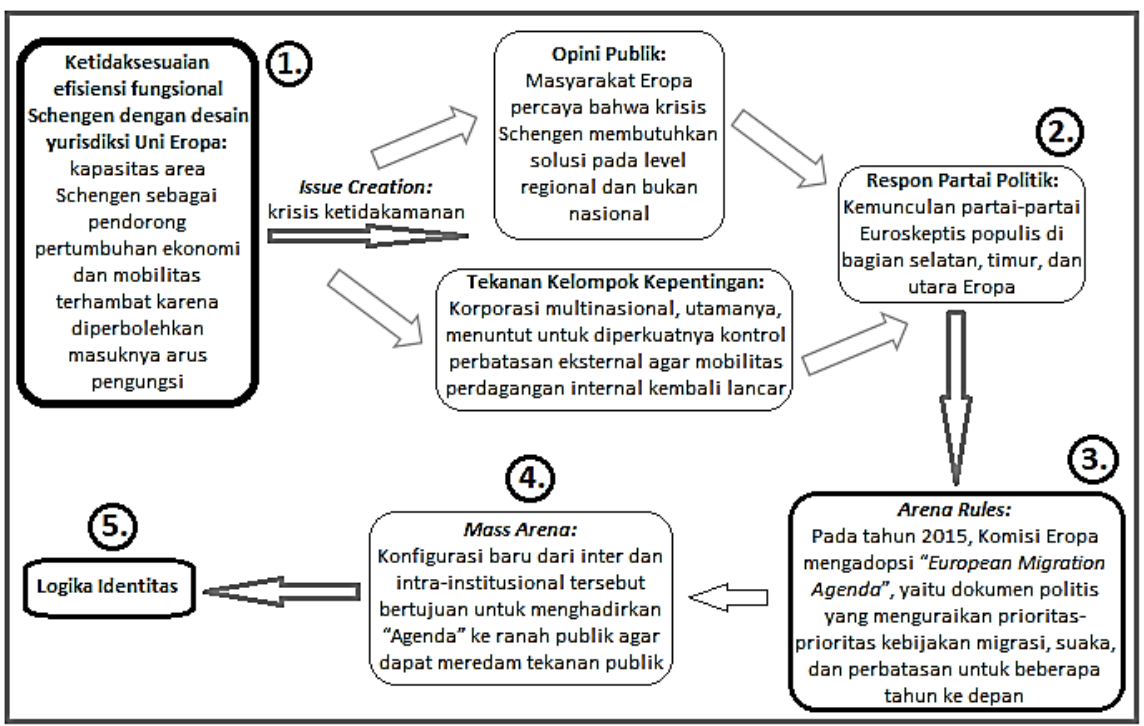

(Sumber: diolah secara pribadi dari berbagai sumber)

Pertama, ketidaksesuaian efisiensi fungsional Schengen tidak sesuai dengan desain yurisdiksi Uni Eropa karena secara fungsional, pembentukan area Schengen ditujukan untuk mendorong pertumbuhan ekonomi dan perdagangan antar negara-negara Eropa, serta mempermudah mobilitas masyarakat Eropa. Meskipun secara khusus terdapat arahan 2004/8, yang menyatakan bahwa setiap warga Uni Eropa berhak untuk bepergian secara bebas tanpa ke negara-negara anggota Uni Eropa yang lainnya, namun dalam desain yurisdiksinya, fitur mobilitas atau pergerakan bebas area Schengen tidak hanya secara khusus diperuntukkan masyarakat Eropa saja, tapi juga untuk masyarakat non-Eropa. "EU citizens, non-EU residents and visitors to the $E U$ need to be able to freely and safely travel within the Union. The Schengen Area has made this a concrete reality." (Komisi Eropa, 2018). Ketika dihadapkan pada masuknya arus pengungsi dalam jumlah besar pada tahun 2015, muncul anomali yang menyebabkan terjadinya issuecreation, yaitu berupa krisis ketidakamanan, yang juga mendorong untuk diadakannya reformasi atau reform impetus dalam desain yurisdiksi area Schengen. 
Kedua, munculnya isu krisis ketidakamanan dalam area Schengen menimbulkan respon dari berbagai lapisan. Secara umum, opini publik menganggap bahwa krisis yang terjadi dalam area Schengen seharusnya diselesaikan dalam kerangka institusi regional Uni Eropa (Borzel dan Risse, 2017). Bukan sebaliknya, yang justru seakan-akan diselesaikan oleh negara-negara anggota Schengen secara individu. Hal ini dapat diamati dari sebuah survei dari tahun 2014 hingga 2016 yang membuktikan bahwa lebih dari dua pertiga masyarakat Uni Eropa mendorong institusi Uni Eropa untuk membentuk kebijakan migrasi bersama sebagai upaya merespon terjadinya krisis pengungsi (Komisi Eropa, 2017). Isu krisis ketidakamanan juga semakin melegitimasi sikap Euroskeptis dari partai-partai populis sayap kanan yang berada di bagian selatan, timur, dan utara Eropa (Kriesi, 2016). Banyak dari partai-partai tersebut akan memobilisasi massa untuk memperkuat identitas nasionalis sekaligus meningkatkan sentimen anti-imigran sebagai bentuk politisasi ketidaksetujuannya terhadap integrasi Eropa. Selain wacana nasionalis, partai-partai populis sayap kanan seperti partai Front National (FN) Perancis, Freedom Party of Austria (FPO) Austria, partai PiS Polandia, Alternative for Germany (AFD) Jerman, juga memunculkan sentimen anti-Islam.

\section{Gambar 2. Perdebatan-perdebatan dalam Forum Publik, Platform Media Sosial Twitter, pada Tahun 2015-2016 terkait Krisis Schengen}

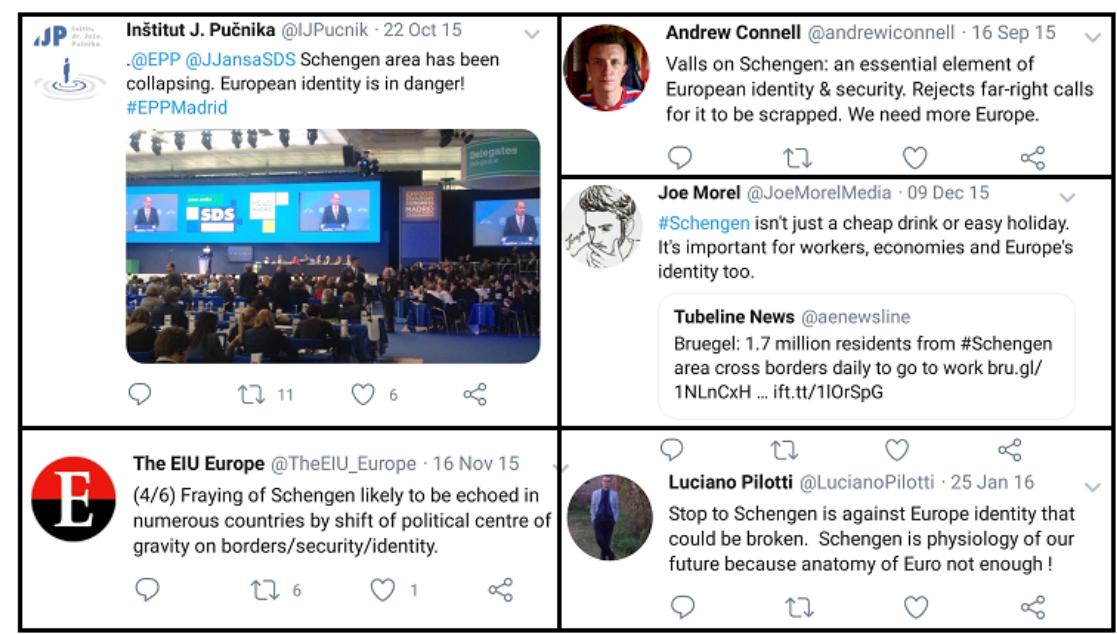

(Sumber: diolah secara pribadi dari berbagai sumber, merujuk media sosial Twitter) 
Kelompok kepentingan terutama kelompok kepentingan ekonomi seperti korporasi multinasional, menuntut untuk diperkuatnya kontrol perbatasan eksternal dan ditingkatkannya pengamanan dalam area Schengen. Dirk Schlotboller selaku perwakilan dari Association of German Chamber of Commerce and Industry (Deutscher Industrie und Handelskammertag, DIHK) dan Dieter Zetsche, selaku Chief Executive Officer (CEO) dari perusahan otomotif multinasional Daimler merupakan beberapa yang mengungkapkan kekhawatiran (Dekcker, 2016). Dikarenakan krisis Schengen berdampak terhadap pariwisata, perdagangan ritel, dan pergerakan kapital lainnya. Model bisnis korporasi-korporasi multinasional Eropa yang bergantung pada open border akan terdampak secara negatif dari krisis migran yang sekaligus juga meningkatkan derajat kompetitif industri.

Ketiga, arena rules atau aturan arena, yaitu merupakan aturanaturan formal yang membatasi keputusan Uni Eropa dalam menentukan ranah fokus reformasi kebijakan institusional ketika menghadapi krisis ketidakamanan. Pada bulan Mei tahun 2015, Komisi Eropa mengadopsi "European Migration Agenda" (Carrera et al., 2015). Dokumen politis tersebut menguraikan prioritas-prioritas kebijakan migrasi, suaka, dan perbatasan Eropa untuk beberapa tahun ke depan. Berbeda dengan pengaturan institusional Uni Eropa sebelumnya, untuk pertama kalinya, agenda kebijakan bersama diadopsi oleh dua badan kerja Uni Eropa secara bersamaan, yaitu European Union for Foreign Affairs and Security Policy (EU FASP) dan Migration, Home Affairs, and Citizenship. Terlebih, reformasi institusional tersebut juga ditujukan sebagai agenda publik karena merupakan bentuk respon Uni Eropa terhadap tekanan publik. Maka, dapat dilihat bahwa Uni Eropa memilih untuk masuk ke dalam mass arena pada bagian skema keempat, sehingga identitas merupakan motif dipertahankannya pengadaan area Schengen meskipun telah menimbulkan berbagai krisis ketidakamanan.

Oleh karenanya, dapat dilihat bahwa sejak dibentuknya Perjanjian Schengen pada tahun 1985, diadopsinya ke dalam kerangka institusi Uni Eropa menjadi Schengen Acquis melalui Perjanjian Amsterdam pada tahun 1999, hingga munculnya krisis pengungsi pada tahun 2015, Schengen berangsur-angsur telah mengalami pergeseran bentuk 'order'. Sebuah area pergerakan bebas lintas batas negara-negara Eropa yang awalnya dibuat dengan motif ekonomi dan mobilitas, dan pada derajat tertentu kepentingan politik ini, keti- 
ka dihadapkan pada sebuah isu menimbulkan anomali institusional. Keterbatasan fungsionalisme dan neofungsionalisme dalam menjelaskan fenomena dipertahankannya area Schengen sebagai salah satu pendorong integrasi regional yang dicanangkan oleh Uni Eropa ini membuat peneliti menganalisis lebih lanjut menggunakan postfungsionalisme. Hal ini dikarenakan, apabila dianalisis lebih lanjut, area Schengen telah mengalami transisi 'ordering', dari ranah fungsional, seperti ekonomi, politik, dan mobilitas, menjadi pada ranah posfungsional, seperti identitas dalam skema integrasi regional oleh Uni Eropa.

\section{Praktik 'Bordering' dalam Mendekonstruksi Identitas Spasial Eropa: Dampak Eksklusi terhadap Non-Eropa}

Pembahasan mengenai definisi identitas Eropa menjadi menarik karena apabila dibandingkan dengan benua-benua yang lainnya, seperti Amerika, Afrika, dan Australia, Eropa relatif tidak memiliki perbatasan-perbatasan alam yang jelas (Wesseling, 2009). Hal ini kemudian terus membuat narasi mengenai identitas Eropa berubah dari waktu ke waktu. Herodotus, seorang sejarawan Yunani Kuno, merupakan salah satu ahli geografi pertama yang mendefinisikan Eropa secara geografis rigid pada abad kelima SM (Parker, 1960). Eropa pertama kali didefinisikan atas perbatasan Hellespont, Laut Marmara, Selat Bosporus, Laut Hitam, dan Laut Kaspia. Lebih lanjut, menurut Hippocrates, seorang ilmuwan Yunani Kuno, Eropa dan Asia dapat dibedakan dalam konteks perbedaan musim yang cukup signifikan antara kedua benua. Hal ini dikarenakan, Asia relatif memiliki fluktuasi musim yang lebih sedikit jika dibandingkan dengan Eropa.

Minimnya perbatasan-perbatasan alam yang bersifat rigid kemudian mulai menggeser narasi mengenai identitas Eropa berdasarkan definisi budaya. Walaupun tidak terlalu umum, namun sejak awal abad pertengahan, Eropa mulai diidentifikasikan dengan kultur yang beradab sehingga berbeda dari kontinen lain yang masih bersifat barbar. Pada awal abad pertengahan, mulai bermunculan identifikasi hubungan antara Eropa dan Kristen, utamanya pasca jatuhnya Konstantinopel pada tahun 1453 (Boer, 1998). Hal ini dikarenakan, Kekaisaran Bizantium telah dianggap sebagai benteng krusial bagi Eropa dalam menghadapi arus persebaran kaum muslim dari Asia, yang mana didukung oleh ekspansi Kekaisaran Turki Ottoman, yang sebelumnya telah menaklukkan Balkan dan 
Anatolia. Oleh karenanya, Paus Pius II dari Keuskupan Roma, mengeluarkan traktat untuk membela Kristen sebagai identitas Eropa dengan istilah "Republica Christiana" dan mencetuskan penggunaan kata "Eropa" sebagai kata sifat dari "europeus", yang mana dalam bahasa Latin diartikan sebagai humanis, untuk membedakan dari kontinen lain yang masih barbar.

\section{Gambar 3. Kontinen Eropa pada tahun 50o SM}

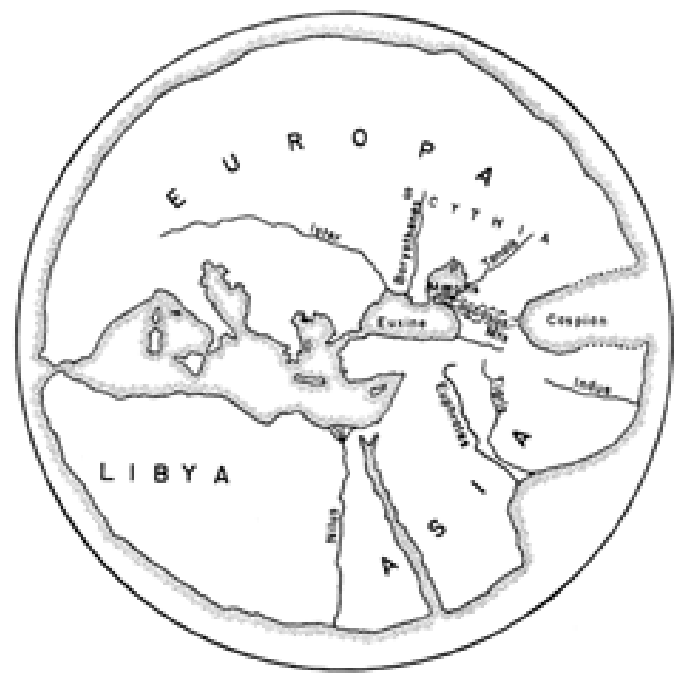

(Sumber: Parker, 1960)

Pada awal era penjelajahan abad ke-15, Eropa digambarkan sebagai 'land beyond the coast', karena luas daratan dan jangkauan luarnya yang tidak jelas dan terus menjadi bahan spekulasi (Boer, 1998). Meskipun pada era-era berikutnya masih terdapat ambiguitas terhadap perbatasan timur Eropa yang berbatasan langsung dengan perbatasan utara Asia, sehingga menyebabkan perdebatan mengenai identitas geografis, utamanya bagi Rusia dan Turki. Namun, pasca Perang Poltava tahun 1709 dan Perjanjian Nystadt tahun 1721, Rusia berhasil memperkuat legitimasinya sebagai bagian dari Eropa karena telah mengalahkan Swedia yang merupakan kekuatan besar di Baltik. Pada awal abad ke-19, Mentelle dan Malte-Brun, ahli geografi dari Perancis kembali memperkuat definisi mengenai perbatasan Eropa, yaitu berupa pegunungan Ural, Sungai Ural, Laut Kaspia, dan Kaukasus, sehingga turut mencakup Rusia dan Turki. 


\section{Gambar 4. Kontinen Eropa pada abad ke-16-17}
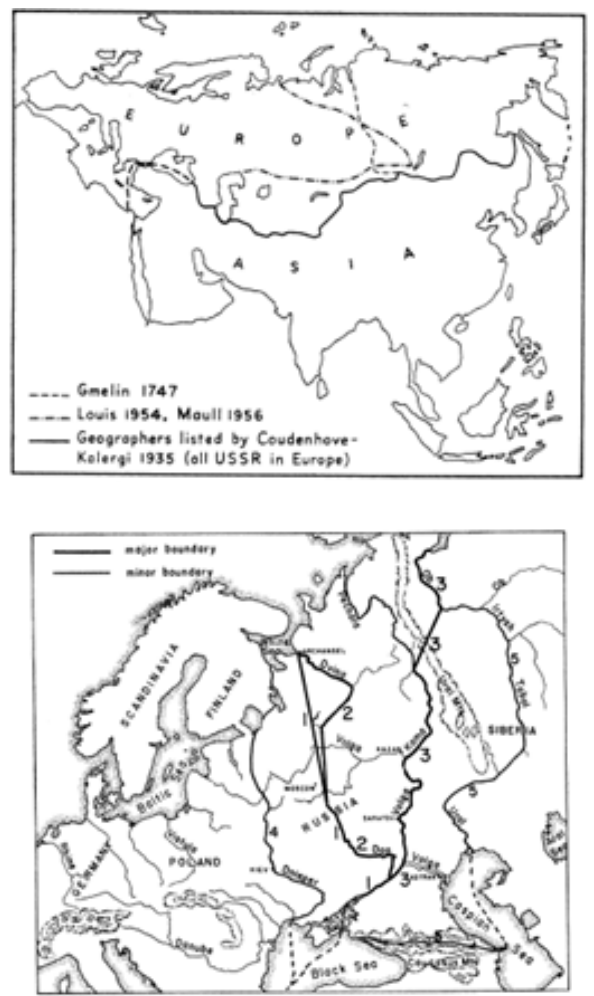

(Sumber: Parker, 1960)

Perbatasan-perbatasan Eropa terus mengalami perubahan secara kontinu yang tidak terlepas dari dampak peperangan, pergantian kerajaan, hingga migrasi massal masyarakat (World Affairs, 2002). Pasca Perang Dingin, terbentuk area Schengen menjadi sebuah tirai baru bagi Eropa, yang diistilahkan sebagai 'Golden Curtain' atau 'Tirai Emas'. Pembentukan tirai baru tersebut merupakan salah satu bentuk praktik 'bordering' dalam upaya rekonstruksi identitas geopolitik spasial Eropa "Tirai Emas" tersebut membentang dari Laut Arktik di sebelah utara Eropa, sampai ke Laut Adriatik di sebelah selatan Eropa, sehingga mencakup Finlandia dan negara-negara Baltik, kecuali negara-negara bekas Yugoslavia selain Slovenia, Kroasia, Romania, dan Bulgaria. Meskipun "Tirai Emas" relatif bersifat lebih fleksibel dan permeabel jika dibandingkan dengan "Iron Curtain" atau "Tirai Besi", namun tidak menutup kemungkinan bahwa dinding pembatas dari "Tirai Emas" dapat menjadi sama ketatnya dengan "TiraiBesi”, terutamabaginegara-negaranon-Eropa. Lebih lanjut, "Tirai Emas" juga digunakan untuk mendefinisikan perbatasan antara negara Eropa dan non-Eropa. 
Diadopsinya Schengen oleh Uni Eropa pada Perjanjian Amsterdam tahun 1999, telah memberikan percepatan pembangunan wilayah lintas batas antar negara Eropa (Veemaa, 2012). Melalui area Schengen, hambatan antara pertukaran budaya dan mobilitas antar negara Eropa juga menjadi semakin minim, sehingga pembentukan identitas regional, secara langsung maupun tidak langsung, menjadi semakin mudah. Pentingnya pembentukan identitas melalui pembangunan kawasan lintas batas dalam proses regionalisasi Eropa merupakan salah satu bahasan literatur studi Regionalisme kontemporer yang cukup banyak dibahas. Beberapa peneliti menyatakan bahwa dalam upaya membentuk kesadaran untuk menciptakan sebuah identitas regional, dapat berlaku dorongan dari dalam maupun luar kawasan. Pada penelitian ini, peneliti berpendapat bahwa pembentukan identitas regional juga dapat diciptakan melalui gagasan representasi spasial oleh aktor regional. Selain itu, praktik 'bordering' area Schengen yang membuat semakin ketatnya hambatan mobilitas bagi negara-negara non-Eropa, berkontribusi dalam memperkuat identitas Eropa dengan mengeksklusikan masyarakat Eropa atau 'the other'.

Diberlakukannya Schengen Acquis kemudian memunculkan narasi konflik yang berfokus pada problematika eksklusi Rusia dari ruang politik, normatif, ekonomi, maupun kultural Eropa . Keprihatinan Rusia terhadap perluasan Uni Eropa, mulai dikemukakan sejak awal kepemimpinan Vladimir Putin pada tahun 1999 (Prozorov, 2005). Pada pertemuan antara Uni Eropa dan Rusia tahun 2000 di Brussel, pemerintah Rusia merilis dokumen kebijakan Rusia terhadap Uni Eropa yang berjudul "The Medium-Strategy for the Development of Relations between the Russian Federation and the EU (200O2010)". Dalam dokumen kebijakan tersebut, area Schengen merupakan salah satu bentuk perluasan Uni Eropa yang menjadi perhatian pemerintah Rusia.

"A common space of freedom, security, and justice - In non-EU parlance, this effort means opening discussions on the long-term prospects for visa-free travel. With the EU's enlargement, Russian citizens will lose the right to visa-free travel in the countries of central and eastern Europe because new member states are required to assume the obligations established by the so-called Schengen regime, currently regulating the control of externalbordersandtheissuanceofvisaswithintheEU.Moscow refers to the Schengen wall as a new Berlin Wall that will split the European continent between insiders in an integrating 
union that takes up most of the continent and outsiders relegated to Europe's sidelines. Putin has gone to great pains to put the question of visa-free travel on the agenda with the $E U$ and has met with some success. Yet, the resolution is a long way off, as the EU is unsatisfied with the state of border control and migration mismanagement in Russia and the CIS, and Russia has still not signed a Readmissions Agreement with the Union" (Lynch, 2004).

Selain itu, diadopsinya area Schengen ke dalam kerangka Uni Eropa semakin memperketat praktik kerja sama bilateral antara Rusia dengan negara-negara anggota baru Uni Eropa, seperti Finlandia, Polandia, dan negara-negara Baltik. Dalam merespon perluasan Uni Eropa tersebut, Rusia mulai membuat Kaliningrad Oblast, sebuah subjek federal dari Federasi Rusia yang terletak di pantai Laut Baltik yang dapat membahayakan pengaturan kerja sama lintas batas antara wilayah Oblast dengan negara-negara tetangga, seperti Lithuania dan Polandia (Lynch, 2004). Praktik 'bordering' berupa eksklusi terhadap Rusia yang diakibatkan oleh pengadaan area Schengen ini juga memicu konflik persepsi Rusia sebagai "European 'Others" atau bahkan "the only European country that is left out of Europe". Hal ini dikarenakan, akses masuk Rusia ke dalam zona 'kebebasan, keamanan, dan keadilan' terus dibendung dan dikontrol sehingga menimbulkan perbedaan identitas. Dampak dari "Schengen Curtain" kemudian tidak hanya menjadi perhatian bagi pemerintah Rusia, namun juga warga dan media Rusia.

Kedua, Turki telah menjadi negara kandidat anggota untuk Uni Eropa, yang tercakup dalam strategi Accession Partnership (AP) pada tahun 2000 (Ozdemir dan Ayata, 2017). Negosiasi aksesi Turki ke dalam Uni Eropa diikuti dengan dibuatnya National Program for the Adoption of the Acquis (NPAA) oleh pemerintah Turki. Akan tetapi sampai sekarang, kebutuhan akan visa selalu menyebabkan hubungan antara Turki dan Uni Eropa menjadi sangat terpolitisasi dan tersekuritisasi. Posisi Turki dalam pengkategorian 'white list' dan 'black list' visa Schengen relatif rumit karena pada satu sisi, terdapat warga negara Turki yang memasuki 'black list' (Peers et al., 2012). Sedangkan di sisi lain, Turki juga sedang dalam proses aksesi ke dalam Uni Eropa sehingga secara teoritis masih di ambang penerimaan sebagai Eropa. Kasus 'white list' dan 'black list' tidak hanya menekankan pada permasalahan keamanan dan migrasi, namun juga permasalahan konstruksi sosial atas ketakutan bersama terhadap 'the other' dan upaya konstruksi masyarakat Eropa terhadap identitas bersama. Oleh karenanya, pemenuhan keperluan visa 
Schengen juga disebut sebagai 'paper wall', karena juga dapat memunculkan identifikasi mengenai Eropa dan non-Eropa, yang mana dalam kasus Turki menjadi ‘belum’ Eropa.

\section{Implikasi 'Spatial "Othering" dalam Krisis Schengen: Peningkatan Derajat Inklusivitas Kerja sama sebagai Re- spon Strategis Negara-negara Eropa}

Secara umum, krisis ketidakamanan yang menimpa area Schengen dapat diklasifikasikan ke dalam dua faktor. Pertama, faktor endogen, Schengen Acquis tidak pernah dipersiapkan untuk menghadapi arus pengungsi dalam jumlah besar pada waktu yang relatif berdekatan (Schimmelfennig, 2018).Sehingga, pembentukan wilayah pergerakan bebas seperti area Schengen, tidak terlepas dari munculnya kebutuhan untuk melakukan harmonisasi kebijakan suaka dalam Uni Eropa, yang diatur dalam transformasi Konvensi Dublin tahun 1990, Dublin II tahun 2003, dan Dublin III tahun 2013. Akan tetapi, sistem Dublin tidak berfungsi secara adil karena, pertama, salah satu kriteria utama yang digunakan adalah penerimaan pencari suaka berdasarkan first country of arrival atau negara pertama yang didatangi para pencari suaka.

Hal ini membuat tanggung jawab penerimaan suaka menjadi tidak proporsional karena relatif memberi beban lebih terhadap negaranegara yang berada di perbatasan eksternal area Schengen, seperti Yunani, Italia, Hungaria, Polandia, dan Spanyol. Kedua, sistem Dublin tidak berfungsi secara efisien sehingga memungkinkan terjadinya "asylum shopping" (Mascarenas, 2015). Hal ini dikarenakan, meskipun sistem Dublin menerapkan kriteria penerimaan berdasarkan first country of arrival, namun kurangnya pengawasan membuat pencari suaka masih dapat mendaftarkan diri ke negaranegara lain sesuai dengan preferensi pribadi.

Kedua, faktor eksogen, krisis Schengen terjadi karena Eropa berbatasan langsung dengan negara-negara yang relatif lemah dan marak konflik, seperti negara-negara Timur Tengah dan Afrika. Pada tahun 2015, memburuknya situasi keamanan di Suriah dan Libya telah memicu sebesar 1,3 juta pengungsi dari dua negara tersebut untuk berpindah dan mencari suaka di Eropa. Dampaknya dengan cepat dirasakan oleh negara-negara anggota Schengen, seperti Swedia, Austria, Finlandia, Jerman, dan Luksemburg (Rittberger et al., 2017). Akan tetapi kemudian, menarik untuk dilihat lebih lanjut terkait 
pilihan respon dari negara-negara anggota Schengen, yaitu antara tindakan yang bersifat unilateral atau kolektif. Hal ini dikarenakan, berbagai kesulitan harmonisasi kebijakan pengungsi dan suaka seharusnya dapat berpotensi menimbulkan kecenderungan negaranegara anggota Schengen untuk menerapkan self-help dan menghasilkan kebijakan-kebijakan yang bersifat beggar-thy-neighbor.

\section{Tabel 2. Lima Negara Anggota Schengen yang Paling Terdampak Krisis Pengungsi Tahun 2015}

\begin{tabular}{|l|l|l|}
\hline State & $\begin{array}{l}\text { Number of } \\
\text { asylum } \\
\text { applicants } \\
\text { per 100.000 } \\
\text { citizens }\end{array}$ & $\begin{array}{l}\text { Number of } \\
\text { accepted } \\
\text { asylum } \\
\text { claims per } \\
100.000 \\
\text { citizens }\end{array}$ \\
\hline Sweden & $\mathbf{1 6 6 4}$ & 330 \\
\hline Austria & $\mathbf{1 0 2 5}$ & 175 \\
\hline Finland & $\mathbf{5 9 7}$ & 31 \\
\hline- Germany & $\mathbf{5 8 8}$ & 174 \\
\hline $\begin{array}{l}\text { Luxem- } \\
\text { bourg }\end{array}$ & $\mathbf{4 4 7}$ & 33 \\
\hline
\end{tabular}

(Sumber: Rittberger et al., 2017)

Setidaknya sepuluh negara anggota Schengen yang paling terkena dampak krisis, yaitu Yunani, Italia, Hungaria, Polandia, Spanyol, Swedia, Austria, Finlandia, Jerman, dan Luksemburg, secara umum mendukung diadakannya respon kolektif strategis dari Uni Eropa dalam menangani ketidakamanan regional. Perubahan iklim keamanan global kemudian membuat European Union Global Strategy for Foreign and Security Policy (EUGS) mulai membuka proses kerja sama yang lebih erat dalam aspek keamanan dan pertahanan regional Eropa (Mogherini, 2017). Negara-negara anggota Uni Eropa pun setuju untuk meningkatkan kerja sama keamanan regional dengan mengadakan peningkatkan koordinasi, investasi, dan pengembangan kapasitas bersama. Pada bulan Desember tahun 2017, Federica Mogherini, High Representative dari European Union for Foreign Affairs and Security Policy (EU FASP), menyatakan bahwa:

"We have activated a Permanent Structured Cooperation on Defence - ambitious and inclusive. Member States have committed to join forces on a regular basis, to do 
things together, spend together, invest together, buy together, act together. The possibilities of the Permanent Structured Cooperation are immense."

Menindaklanjuti Perjanjian Uni Eropa tahun 1995, pasal 42(6) dan 46, serta Protokol 10, pembentukan European Defence Fund (EDF) dan Permanent Structured Cooperation on Security and Defence (PESCO) ditujukan untuk meningkatkan efektivitas penanganan tantangan keamanan regional (Rahvusvaheline Kaitseuuringute Keskus, 2017). Selain itu, PESCO juga ditujukan untuk meningkatkan laju integrasi dalam kerangka Uni Eropa. Diinisiasinya badanbadan pertahanan baru, seperti EDF dan PESCO, dapat menjadi pencapaian yang signifikan dalam kapabilitas keamanan Eropa. Saat ini, tidak dipungkiri bahwa pertahanan kolektif Eropa masih berada di bawah peranan NATO.

Menurut peneliti, meskipun kolaborasi pertahanan dan keamanan dengan NATO masih dibutuhkan, namun perlu untuk digarisbawahi pentingnya pembentukan badan keamanan dan pertahanan yang berbeda dari NATO, agar dapat menyesuaikan potensi dan strategi tiap negara Eropa. Konsep penghapusan batasan internal untuk mempermudah pergerakan bebas manusia antar negara Eropa yang diberlakukan oleh area Schengen kemudian menjadi cikal bakal konsep penghapusan batasan hukum untuk mempermudah pergerakan bebas pasukan militer antar negara Eropa, atau yang dikenal sebagai "Military Schengen Zone" (EEAS, 2018). Oleh karenanya, dapat dilihat bahwa krisis Schengen justru menjadi momentum politik bagi Uni Eropa untuk meningkatkan integrasi regional ke level yang lebih tinggi dari sebelum-sebelumnya, yaitu peningkatan kebebasan kerja sama keamanan dan pertahanan regional.

Berdasarkan wawancara peneliti dengan Charles Guertz, Wakil Kepala Delegasi pada European External Action Service (EEAS) (Guertz, 2018), PESCO merupakan proyek baru yang sangat konkrit dalam memperkuat dan melengkapi dimensi pertahanan integrasi Eropa. Dikarenakan sejauh ini, Uni Eropa masih belum memiliki kebijakan manajemen pertahanan yang dapat sepenuhnya merespon tantangan global maupun geopolitik. Sehingga, PESCO dapat meningkatkan operabilitas internal, yang mencakup infrastruktur, kecepatan kerja sama, serta pergerakan aset-aset militer dalam Uni Eropa. Hal ini menjadi penting, karena apabila dikaitkan dengan krisis keamanan Schengen yang diakibatkan oleh maraknya terorisme dan krisis pengungsi, dibutuhkan aspek keamanan 
yang tidak hanya dapat melakukan standarisasi kebijakan, namun juga kemampuan untuk memastikan keamanan pada perbatasan eksternal bersama.

\section{Kesimpulan}

Tulisan ini bertujuan untuk menjelaskan adanya motif identitas sebagai faktor di balik dipertahankannya area Schengen dalam skema integrasi Eropa. Lebih lanjut, menurut peneliti, pada derajat tertentu, Eropa juga membutuhkan munculnya kondisi ketidakamanan, utamanya yang datang dari luar. Negara-negara Eropa relatif tidak memiliki 'common enemies' atau musuh bersama karena sejak awal justru selalu bersitegang antar satu sama lain dalam peperangan, bahkan sampai Perang Dunia II. Masuknya arus pengungsi dalam jumlah besar, yang kemudian menyebabkan berbagai krisis ketidakamanan, membentuk identitas Eropa secara interaktif, meskipun tidak secara langsung mendefinisikan "who and what 'we' are" namun dapat memperjelas "who or what 'we' are not" maupun "what 'we' have to fear".

Maka, tulisan ini berkontribusi untuk memberikan tinjauan alternatif mengenai peran area Schengen dalam proses integrasi regional Eropa. Berdasarkan tiga indikasi yang telah dikemukakan pada argumen, terkonfirmasi bahwa dipertahankannya area Schengen di bawah kerangka institusi Uni Eropa karena pertama, area Schengen telah mengalami transisi bentuk 'ordering', dari yang awalnya bermotif fungsional menjadi sarat akan motif identitas, yang ditunjukkan dengan sebab kedua yaitu munculnya praktik 'bordering' sebagai upaya dekonstruksi identitas geografis rigid Eropa menjadi identitas geopolitik spasial yang relatif lebih 'konkret' dan 'terkontrol'. Ketiga yaitu peningkatan derajat inklusivitas integrasi regional Eropa sebagai bentuk respon strategis 'spatial "othering" terhadap non-Eropa sehingga identitas Eropa yang berusaha untuk dikonstruksikan dalam upaya integrasi regional yang dicanangkan Uni Eropa semakin terlegitimasi.

Akhirnya, untuk penelitian-penelitian selanjutnya, menarik untuk melihat pola integrasi Eropa melalui kacamata yang lebih luas, terutama yang dilandasi oleh pernyataan Jean Monnet, salah satu pencetus integrasi Eropa, dalam laporan riwayat hidupnya bahwa "always believed that Europe would be built through crises, and that it would be the sum of their solutions". Dikarenakan, dalam 
proses pengerjaan tulisan ini, secara umum, peneliti melihat bahwa pembentukan main treaties atau hukum-hukum primer Uni Eropa sejak tahun 1950 hampir selalu ditujukan sebagai respon atas krisis besar yang menimpa Eropa, mulai dari krisis kepercayaan pasca Perang Dunia II, krisis minyak tahun 1970-an, krisis independensi pasca Perang Dingin, hingga krisis finansial tahun 2008. Terlebih, pilihan negara-negara Eropa untuk menyelesaikan berbagai krisis ketidakamanan yang disebabkan oleh arus pengungsi tahun 2015 secara kolektif dan bukan unilateral, juga semakin membuka peluang untuk meningkatkan derajat inklusivitas integrasi regionalnya, yaitu pada aspek keamanan, yang mana selama ini kurang menjadi fokus utama. Sebagai tambahan, juga menarik untuk dilihat kemunculan wacana identifikasi identitas geopolitik "Eurasia" sebagai alternatif bagi negara-negara yang tereksklusi dari Eropa dan Asia. 


\section{Daftar Pustaka}

\section{Buku}

Derrida, Jacques. 1968. “La Difference”, dalam Theorie d'Ensemble.

Farrell, Mary, Bjorn Hettne, dan Luk Van Langenhove. 2005. "The Global Politics of Regionalism: An Introduction", dalam Global Politics of Regionalism: Theory and Practice. London: Pluto Press.

Guertz, Charles-Michel. 2018. Komunikasi Personal, pada 31 Mei 2018.

Peers, Steve, Elspeth Guild, dan Jonathan Tomkin. 2012. "EU Immigration and Asylum Law (Text and Commentary): Second Revised Edition", dalam Immigration and Asylum Law and Policy in Europe.

Veemaa, Jaanus. 2012. "Internationalizing the Spatial Identity of Cross-Border Cooperation”, dalam European Planning Studies.

\section{Jurnal Ilmiah}

Boer, Pim den. 1998. "Europe as an Idea”, dalam European Review, Vol. 6, Issue 04.

Borzel, Tanja dan Thomas Risse. 2017. "From the euro to the Schengen crises: European integration theories, politicization, and identity politics", dalam Journal of European Public Policy.

Campbell, David. 1990. "Global Inscription: How Foreign Policy Constitutes the United States", dalam Alternatives: Global, Local, Political, Vol. 15, No. 3.

Carrera, Sergio, Steven Blockmans, Daniel Gros, dan Elspeth Guild. 2015. "The EU's Response to the Refugee Crisis: Taking Stock and Setting Policy Priorities", dalam Centre for European Policy Studies.

Checkel, Jeffrey. 2006. "Constructivist Approaches to European Integration”, dalam Handbook of European Union Politics. 
Houtum, Henk Van dan Ton Van Naerssen. 2001. "Bordering, Ordering, and Othering", dalam Human Geography. Nijmegen: Nijmegen Centre for Border Research.

Kriesi, H. 2016. "The Politicization of European Integration”, dalam Journal of Common Market Studies 54.

Mascarenas, Blanca. 2015. "Why Dublin "Doesn't Work"”, dalam Barcelona Centre for International Affairs.

Ozdemir, Zelal dan Ayse Gunes Ayata. 2017. "Dynamics of Exclusion and Everyday Bordering through Schengen Visas", dalam Political Geography.

Parker, W. H. 1960. "Europe: How Far?”, dalam The Geographical Journal, Vol. 126, No. 3.

Prozorov, Sergei. 2011. "The Other as Past and Present: Beyond the Logic of 'Temporal Othering' in IR Theory”, dalam Review of International Studies, Vol. 37, No. 3.

Rittberger, Berthold, Felix Biermann, Nina Guerin, Stefan Jagdhuber, dan Moritz Weiss. 2017. "Explaining Uneven EU Integration Trajectories: A Comparison of the Euro Crisis and the Refugee Crisis", dalam European Union Studies Association.

Schimmelfennig, Frank. 2018. "European Integration (Theory) in Times of Crisis: A Comparison of the Euro and Schengen Crisis", dalam Journal of European Public Policy, Vol. 25, No. 7.

Wesseling, H. L. 2009. “What is Europe?”, dalam European Review, Vol. 6, No. 4 .

World Affairs. 2002. "Defining the Borders of the New Europe", dalam Where does Europe End? The Politics of NATO and EU Enlargement, World Affairs, Vol. 164, No. 4.

\section{Artikel Daring}

Aamann, Preben. 2016. "Report by President Donald Tusk to the European Parliament on the March European Council meeting” [Online], dalam http://www.consilium.europa.eu/en/ 
press/press-releases/2016/o4/13/tusk-report-european-parliament/ [diakses pada 16 Agustus 2017].

Dallison, Paul. 2016. "Juncker 'not going to give up on Schengen" [Online], dalam https://www.politico.eu/article/juncker-notgoing-to-give-up-on-schengen-borders-migration/ [diakses pada 15 Agustus 2017].

Dekcker, Janosch. 2016. "Backlash grows to Schengen backlash: Business raises alarms about the high cost of restoring borders in Europe" [Online], dalam https://www.politico.eu/article/ backlash-grows-to-schengen-backlash-migration-crisis-borders-terrorism-security-borderless-europe/ [diakses pada 10 September 2017].

EurLex. 2000. "Convention: Implementing the Schengen Agreement" [Online], dalam http://eur-lex.europa.eu/legal-content/ $\mathrm{EN} / \mathrm{TXT} / \mathrm{HTML} /$ ?uri=CELEX:42000A0922(02)\&from=EN [diakses pada 20 Januari 2018].

European External Action Service (EEAS). 2018. "The Common Security and Defence Policy (CSDP)" [Online], dalam https:// eeas.europa.eu/headquarters/headquarters-homepage/431/ common-security-and-defence-policy-csdp_en [diakses pada 25 April 2018]

Jenkins, Nash. 2016. "A Timeline of Recent Terrorist Attacks in Europe" [Online], dalam http://time.com/4607481/europeterrorism-timeline-berlin-paris-nice-brussels/ [diakses pada 10 Agustus 2017].

Joannin, Pascale. 2014. "The Free Movement of People in the European Union: principle, stakes and challenges" [Online], dalam https://www.robert-schuman.eu/en/europeanissues/o312-the-free-movement-of-people-in-the-europeanunion-principle-stakes-and-challenges [diakses pada $20 \mathrm{Ma}-$ ret 2018].

Komisi Eropa. 2011. 2011. "Europe without borders: The Schengen area" [PDF], dalam https://ec.europa.eu/home-affairs/sites/ homeaffairs/files/e-library/docs/schengen_brochure/schengen_brochure_dr3111126_en.pdf [diakses pada 4 Agustus 2017].

. 2015. "European Commission Statement following the 
temporary reintroduction of border controls by Germany, particularly at the German-Austrian border" [Online], dalam http://europa.eu/rapid/press-release_STATEMENT-15-5638_en.htm [diakses pada 10 Agustus 2017].

. 2017. "Public Opinion: A Common European Policy on Migration 2014-2016" [Online], dalam http://ec.europa. $\mathrm{eu} / \mathrm{COMMFrontOffice/publicopinion/index.cfm/Chart/}$ getChart/themeKy/29/groupKy/180 [diakses pada 9 September 2017].

. 2018. "Schengen, Borders \& Visas" [Online], dalam https:// ec.europa.eu/home-affairs/what-we-do/policies/bordersand-visas_en [diakses pada 10 Januari 2018].

Lynch, Dov. 2004. "Russia's Strategic Partnership with Europe" [PDF], the Washington Quarterly, dalam https://www.iss.europa.eu/sites/default/files/EUISSFiles/analyo77.pdf [diakses pada 20 April 2018].

Mogherini, Federica. 2017. "Permanent Structured Cooperation (PESCO) - Factsheet” [Online], dalam https://eeas.europa.eu/ headquarters/headquarters-homepage/34226/permanentstructured-cooperation-pesco-factsheet_en [diakses pada 25 April 2018].

Parlemen Eropa. 2016. "At a Glance: the Economic Impact of Suspending Schengen" [PDF], dalam http://www.europarl. europa.eu/RegData/etudes/ATAG/2016/579074/EPRS_ ATA(2016)579074_EN.pdf [diakses pada 11 Agustus 2017].

. 2016. "Refugee and migration crisis: the financial cost" [Online], dalam https://www.europarltv.europa.eu/programme/security/refugee-and-migration-crisis-the-financialcost [diakses pada 15 Agustus 2017].

. 2016. "Schengen Border Controls: Challenges and Policy Options" [PDF], dalam http://www.europarl.europa.eu/RegData/etudes/IDAN/2016/578990/IPOL_ IDA\%282016\%29578990_EN.pdf [diakses pada 15 Agustus 2017].

. 2018. "Schengen: enlargement of Europe's border-free area" [Online], dalam http://www.europarl.europa.eu/news/ en/headlines/security/20180216STO98008/schengen- 
enlargement-of-europe-s-border-free-area [diakses pada 3 Maret 2018].

Prozorov, Sergei. 2005. "The Structure of the EU-Russia Conflict Discourse: Issue and Identity Conflicts in the Narratives of Exclusion and Self-Exclusion", Working Papers Series No. 13, EU Border Conflicts Studies, dalam https://www.birmingham.ac.uk/Documents/college-social-sciences/governmentsociety/polsis/research/2006/eu-border-conflict/wp13-thestructure-of-the-eu-russian-conflict-discourse.pdf [diakses pada 14 April 2018].

Spolaore, Enrico. 2013 "What is European Integration Really about? A Political Guide for Economists" [PDF], dalam http://sites. tufts.edu/enricospolaore/files/2012/o8/Euro-June-2013.pdf [diakses pada 10 Agustus 2017].

\section{Conference Paper}

Rahvusvaheline Kaitseuuringute Keskus (RKK). 2017. "European Defence Cooperation: Out of the Shadows?" [Online], Annual Baltic Conference on Defence 2017 dalam http://abcd.icds. ee/16-2017 [diakses pada 25 April 2018]. 